\title{
Validation of the Skindex-29 Questionnaire: Portuguese Version (Portugal)
}

\section{Validação do Questionário Skindex-29: Versão Portuguesa (Portugal)}

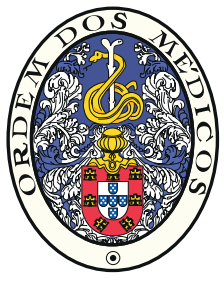

\author{
Daniela CARVALHO ${ }^{1}$, Pedro AGUIAR ${ }^{1}$, Antero PALMA-CARLOS ${ }^{2}$ \\ Acta Med Port 2018 Sep;31(9):463-469 - https://doi.org/10.20344/amp.9850
}

\section{ABSTRACT}

Introduction: There is an increasing interest regarding the impact of skin diseases on quality of life. Skindex-29 is a questionnaire developed to evaluate this impact. This study aimed to validate Skindex-29 for the Portuguese population.

Material and Methods: From the 81 approached patients from two clinics, only 75 finished the study: 35 with skin disease and 40 without. A translation and back-translation were performed. Concerning accuracy and discrimination power, the scores were submitted to ROC curve analysis after being compared between both groups through Mann-Whitney test. Internal consistency was measured using Cronbach's $\alpha$ coefficient. Test/retest of each scale was assessed by the intra-class correlation coefficient, and by Kappa coefficient of agreement. Convergent validity was evaluated through Spearman correlations between Skindex-29 scores and SF-12 subscales. SPSS statistics and values of $p<0.05$ with $95 \%$ confidence intervals were considered statistically significant.

Results: The Skindex-29 demonstrated to be an accurate instrument and statistically significant differences were found when comparing the disease and without-disease groups $(p<0.001)$. The reliability was high (Cronbach's $\alpha>0.80)$ for each dimension ('Symptoms', 'Emotions' and 'Functioning') and for test-retest (ICC > 0.90, K > 0.494). About convergent validity, Skindex-29 Total score and the questions about 'Symptoms' and 'Functioning' were statistically correlated with the questions regarding the physical state of the SF-12 (-0.478; -0.459; -0.405 , respectively).

Discussion: Results suggest that Skindex-29 can be used as an instrument to evaluate skin diseases' effect on quality of life in Portugal, being accurate and reliable. Despite having similar general health profiles as other individuals, dermatological patients showed a lower quality of life due to their disease. Results showed that Skindex-29 was better at assessing physical components rather than mental or emotional components.

Conclusion: Skindex-29 appears to have evidence of validity including accuracy and reliability to be used as an instrument to evaluate the impact of skin diseases on quality of life in Portugal.

Keywords: Portugal; Quality of Life; Skin Diseases; Surveys and Questionnaires

\section{RESUMO}

Introdução: Verifica-se um interesse crescente no que diz respeito ao impacto da qualidade de vida em doenças dermatológicas. O Skindex-29 é um questionário desenvolvido para avaliar tal impacto. Este estudo teve como objetivo validar o questionário para a população Portuguesa.

Material e Métodos: Dos 81 indivíduos abordados, provenientes de duas clinicas, apenas 75 terminaram o estudo: 35 com doença dermatológica e 40 sem doença. Uma tradução e retroversão foram feitas. Acerca da precisão e poder discriminante, os scores foram comparados entre os grupos, utilizando o teste de Mann-Whitney. A consistência interna foi medida usando o coeficiente $\alpha$ de Cronbach. A análise teste-reteste foi realizada usando o coeficiente de correlação intraclasse e o coeficiente de concordância Kappa. A validade convergente foi avaliada através de correlações de Spearman entre os scores de Skindex-29 e as subescalas do SF-12. Os valores de $p<0,05$ e as estatísticas de SPSS com intervalo de confiança de $95 \%$ foram considerados significativos.

Resultados: O Skindex-29 demonstrou ser um instrumento preciso e discriminante dado existirem diferenças estatisticamente significativas entre os grupos com e sem doença $(p<0,001)$. A confiabilidade foi alta ( $\alpha$ de Cronbach $>0,80)$ para cada dimensão ('Sintomas', 'Emoções' e 'Funcionalidade'), assim como para teste-reteste (ICC < 0,90, K < 0,494). Acerca da validade convergente, o score total do Skindex-29 e as perguntas sobre 'Sintomas' e 'Funcionalidade' foram estatisticamente correlacionados com as questões sobre estado físico do SF-12 (-0,478; -0,459; -0,405, respetivamente).

Discussão: O Skindex-29 parece evidenciar validade, incluindo precisão e confiabilidade, para ser usado na avaliação da qualidade de vida dos indivíduos com doenças cutâneas em Portugal. Os pacientes dermatológicos assumem uma saúde geral semelhante à dos restantes. Contudo, destacando a própria doença, revelam menores níveis de qualidade de vida. O Skindex-29 mostrou-se mais robusto na avaliação dos componentes físicos do que dos componentes mentais ou emocionais.

Conclusão: Skindex-29 parece ter evidência de validade, incluindo precisão e confiabilidade para ser usado como instrumento para avaliar a qualidade de vida das doenças da pele em Portugal.

Palavras-chave: Doenças de Pele; Inquéritos e Questionários; Portugal; Qualidade de Vida

\section{INTRODUCTION}

The skin is the body's first line of immune defence, providing a protective barrier against bacteria, chemicals, and physical insults while maintaining homeostasis of the internal environment. ${ }^{1}$ Although skin diseases are not life-

threatening, the irritating, painful and disfiguring nature of the disease can profoundly affect the quality of life (QoL) of patients and their families. ${ }^{2}$ For the World Health Organization, QoL is the "individual perception of one's

\footnotetext{
1. Public Health Research Center. NOVA University of Lisbon. Lisboa. Portugal.

2. CAIC - Clinica de Alergia e Imunologia Clinicas. Lisboa. Portugal.

$\triangle$ Autor correspondente: Daniela Carvalho. dfcarvalho@vodafone.pt

Recebido: 23 de outubro de 2017 - Aceite: 11 de junho de 2018| Copyright $\odot$ Ordem dos Médicos 2018
} 
position in life within the context of the cultural system and the values one lives in as well as in relation to one's goals, expectations, norms and concerns". Health-related QoL is a multidimensional concept that includes physical, emotional, and social components associated with its disease. ${ }^{3}$ Earlier research has shown that skin diseases impact the patients' QoL, and measuring it is challenging. ${ }^{4}$ In dermatology, studies have shown that patients who suffer from a variety of different skin diseases have a severely reduced QoL. ${ }^{5}$

It is important that the methodology used accurately measures the impact of disease on QoL for use in clinical practice, research studies, and economic analyses. ${ }^{2}$

Everyday tasks that are potentially affected by skin diseases include aspects of physical and emotional wellbeing, the individual's social life, and performance at work or school. As symptoms of skin diseases are often visible and affect an individual appearance, patients may have difficulties with emotional status and social interactions. In summary, individuals' lives are often seriously disrupted by their skin disease, impacting their QoL. ${ }^{5}$

The Skindex-29 questionnaire is used in several countries with different health systems and cultures. It is therefore important that it be translated, and a cultural re-adaptation made (inclusive of immigrant populations). This need has become more pressing with the increasing number of large multicentre and multicultural trials. ${ }^{6}$

The Skindex-29 is a disease-specific questionnaire comprehensively assessing the effects of skin diseases on patients' QoL. Originally developed in English (USA), it was adapted to several languages like German, ${ }^{5}$ Spanish (Spain, ${ }^{4}$ Argentine, ${ }^{7}$ Colombia ${ }^{8}$ ), Italian, ${ }^{9}$ Turkish, ${ }^{10}$ Polish, ${ }^{11}$ and even Brazilian Portuguese. ${ }^{12}$ Despite the language being similar, there are known cultural differences between Portugal and Brazil, ${ }^{6}$ and validation of the QoL questionnaire for these two countries separately is necessary to complete a cultural re-adaptation. The questionnaire assesses areas considered essential in evaluating patient's QoL. These include: burden of symptoms, social function, and emotional state; and is therefore divided into three dimensions: Emotions, Symptoms and Functioning. ${ }^{12}$

Therefore, this study aimed to validate the Skindex-29 for one more country, Portugal.

\section{MATERIAL AND METHODS}

The first step was to ask Mapi Research Trust for authorization to use Skindex-29 and QualityMetric to use the Portuguese version of SF-12. This organization provides access to the respective questionnaire, with the appropriate authorization.

Patients were enrolled between October 2016 and December 2016 at the CAIC clinic (Centro de Alergologia e Inmunologia Clínica) and DermaCare, in Lisbon, with respective authorizations. The sample was assembled by statistical convenience and patients were not selected for their personal information, such as age or gender. The sample was divided into two groups: with-disease and without-disease. Patients with skin disease were included in the 'disease group' if they were $\geq 18$ years old and within the last five years had been diagnosed with skin disease or an exacerbation of the disease. Patients within the 'without-disease group' did not have any skin problem and were $\geq 18$ years old. A total of 81 patients were selected. However, three refused to participate, two did not complete the questionnaire, and one questionnaire was withdrawn because the informed consent was not correctly signed. Therefore, 75 patients completed the questionnaire, 35 of which had skin problems (included in the disease group) and the remaining 40 were included in the without-disease group. For validation studies in this area, the sample size varies greatly. However, values on the range of 30 60 individuals are commonly used in these immediate validations. ${ }^{12,14-16}$

The participants signed an informed consent form with all the necessary information for the study and were informed that they could give up or refuse to participate. After signing the informed consent, the Skindex-29 and SF12 were applied in interview form. SF-12 (12-Item Short Form Health Survey) is a set of generic, coherent, and easily administered QoL measures. ${ }^{17}$

Age and gender were the only sociodemographic characteristics analysed, by descriptive analysis (frequencies or mean, median, standard deviation, minimum and maximum). To evaluate the discriminating power of Skindex-29 we performed ROC curve analysis. A Spearman coefficient correlation was obtained to analyse the correlation between each item and its respective dimension, as well as between each dimension and the total score.

Initially, a translation of the questionnaire from English into Portuguese was carried out; then the translated questionnaire was evaluated and corrected by specialists in the area (Immunoalergologists with vast experience with dermatologic allergic diseases). Thereafter, a backtranslation was made from Portuguese to English by dermatologists with experience in eczema and urticaria. Construction validity was assessed clinically and psychometrically.

Concerning accuracy, the scores of Skindex-29 were compared with an independent gold standard definition of the disease: disease group versus without-disease group. The Mann-Whitney test was used to compare both groups. ${ }^{18,19}$

Internal consistency was measured using Cronbach's a coefficient between scores. Regarding test-retest, 26 patients repeated the Skindex-29 three weeks later (four refused to repeat the questionnaire and five could not be contacted again). The test-retest of each Skindex-29 scale was assessed computing the intra-class correlation coefficient (ICC) between scores on the first and second participation and measured by the Cohen's Kappa coefficient of agreement between items. ${ }^{18,19}$

According to Landis and Koch (1997), concordance is slight, fair, moderate, substantial or almost perfect if Kappa is respectively within $0.01-0.20,0.21-0.40,0.41-0.60$, 


\section{$0.61-0.80$ or $0.81-1.00 .^{20,21}$}

The Wilcoxon test was used as a complement for testretest evaluation, comparing distribution of both Skindex-29 administrations, by dimension.

The convergent validity of Skindex-29 with SF-12 was then evaluated through Spearman correlations between the Skindex-29 scores and the SF-12 derived subscales.

The Skindex-29 Score was calculated as described in other validations $\mathbf{s}^{4,6,10,12,22}$ and according to the guideline provided by the copyright owner: higher values indicate a more negative QoL index. The questionnaire is divided into three dimensions: 'Emotions', 'Functioning' and 'Symptoms'. The values for each dimension are expressed in a linear scale. Skindex-29 contains 30 items, but the number 18 is often taken out in validations. This item asks about adverse effects to treatments and was thus not included in any of the dimensions. For the total score all items are included. For the 'Emotions' dimension the questions included are 3 , $6,9,12,13,15,21,23,26$ and 28. For the 'Symptoms', items 1, 7, 19, 24 and 27. Lastly, questions 2, 4, 5, 8, 11, 14, $17,20,22,25,29$ and 30 are grouped in the 'Functioning' dimension. Each item is rated on a 5-point Likert scale (never, rarely, sometimes, often, and always). All responses are transformed on a scale of 0 to 100 ( 0 for a positive effect on patient QoL and 100 for negative effect). Scale scores are calculated by averaging the responses to items of a given dimension.

The SF-12 questionnaire was analyzed with the
Health Outcomes Scoring Software 5.0 program. Values of $p<0.05$ were considered statistically significant and confidence intervals were determined with 95\% confidence. All analyses were performed using the IBM SPSS Statistics 22 for Windows program.

\section{RESULTS \\ Individual patient characteristics}

With a total of 35 participants with-disease and 40 participants without-disease, the sample was characterized according to gender and age (Table 1). For both groups, the percentage of females was higher than males. In addition, participants in the without-disease group were older than participants in the disease group. In spite of this, there was no correlation between age and scores of Skindex-29. Concerning the disease group, the Spearman rank order correlation coefficient was not statistically significant, presenting weak correlation coefficients: $-0.129(p=0.461)$; $-0.170(p=0.329) ;-0.042(p=0.812)$ and $-0.111(p=0.525)$ for total score, 'Emotions', 'Symptoms' and 'Functioning', respectively. Similar results were obtained for the withoutdisease group, in the same order: $-0.069(p=0.672) ;-0.149$ ( $p=0.359),-0.009(p=0.954)$ and for 'Functioning', it was not possible to determine (data not shown).

Individuals with different dermatological diseases were included in this validation. The different conditions observed are presented in Table 2. The category 'other diseases' included one case for each of the following dermatological

Table 1 - Sociodemographic characterization of the participants

\begin{tabular}{llccc}
\hline \multirow{2}{*}{ Gender } & Male & $\begin{array}{c}\text { Total } \\
(\mathbf{n = 7 5 )}\end{array}$ & $\begin{array}{c}\text { Patients } \\
(\mathbf{n}=\mathbf{3 5})\end{array}$ & $\begin{array}{c}\text { Non patients } \\
(\mathbf{n}=\mathbf{4 0})\end{array}$ \\
& Female & $37.3 \%$ & $37.1 \%$ & $37.5 \%$ \\
\multirow{3}{*}{ Age } & Mean & $62.7 \%$ & $62.9 \%$ & $62.5 \%$ \\
& Median & 47.97 & 41.11 & 53.98 \\
& Standard deviation & 48 & 43 & 60.50 \\
& Minimum & 17.85 & 14.79 & 18.29 \\
& Maximum & 18 & 18 & 18 \\
\hline
\end{tabular}

Table 2 - Distribution of diseases and symptoms found in the individuals from the clinic

\begin{tabular}{lcc}
\hline Disease & Frequency & $\%$ \\
\hline Eczema & 9 & 12 \\
Eczema and other allergic diseases & 5 & 6.7 \\
Eczema and other cutaneous manifestations & 2 & 2.7 \\
Urticaria & 3 & 4.0 \\
Urticaria and other allergies & 2 & 2.7 \\
Eczema and Urticaria & 1 & 1.3 \\
Cutaneous manifestations & 4 & 5.3 \\
Cutaneous manifestations and other allergies & 3 & 4.0 \\
Dermatitis & 1 & 1.3 \\
Other diseases & 5 & 6.7 \\
Non dermatological disease & 40 & 53.3 \\
\hline
\end{tabular}


Table 3 - Statistical inference of Total Scores and Skindex-29 dimensions among patients, $1^{\text {st }}$ and $2^{\text {nd }}$ participations and non-patients

\begin{tabular}{|c|c|c|c|c|c|c|c|c|}
\hline & & Mean & Median & $\begin{array}{l}1^{\text {st }}-3^{\text {rd }} \\
\text { Quartile }\end{array}$ & Minimum & Maximum & $\begin{array}{l}\text { Area under the } \\
\text { ROC }\end{array}$ & $p$ value \\
\hline \multirow[t]{3}{*}{$\begin{array}{l}\text { Total score } \\
\text { (No of items: 29) }\end{array}$} & $\begin{array}{l}\text { Disease } \\
\text { group } 1^{\text {st }}\end{array}$ & 34.63 & 30.17 & $15.52-52.59$ & 6.03 & 82.76 & $\begin{array}{c}0.982 \\
p<0.001 \\
\mathrm{Cl}] 0.961 ; 1[\end{array}$ & \\
\hline & $\begin{array}{l}\text { Disease } \\
\text { group } 2^{\text {nd }}\end{array}$ & 37.53 & 33.62 & $20.47-56.90$ & 12.07 & 84.48 & & $0.861^{*}$ \\
\hline & $\begin{array}{l}\text { Without- } \\
\text { disease } \\
\text { group }\end{array}$ & 2.31 & 0.86 & $0.00-3.45$ & 0 & 12.93 & & $p<0.001^{+}$ \\
\hline \multirow[t]{3}{*}{$\begin{array}{l}\text { Score of } \\
\text { 'Emotions' } \\
\text { (No of items: 10) }\end{array}$} & $\begin{array}{l}\text { Disease } \\
\text { group } 1^{\text {st }}\end{array}$ & 35.71 & 32.50 & $15.00-50.00$ & 0 & 82.50 & $\begin{array}{c}0.957 \\
p<0.001 \\
\mathrm{Cl}] 0.911 ; 1[\end{array}$ & \\
\hline & $\begin{array}{l}\text { Disease } \\
\text { group } 2^{\text {nd }}\end{array}$ & 37.7 & 31.25 & $24.38-51.25$ & 2.50 & 82.50 & & $0.360^{*}$ \\
\hline & $\begin{array}{l}\text { Without- } \\
\text { disease } \\
\text { group }\end{array}$ & 2.50 & 0 & $0.00-2.50$ & 0 & 15 & & $p<0.001^{+}$ \\
\hline \multirow[t]{3}{*}{$\begin{array}{l}\text { Score of } \\
\text { 'Symptoms' } \\
\text { (No of items: 7) }\end{array}$} & $\begin{array}{l}\text { Disease } \\
\text { group } 1^{\text {st }}\end{array}$ & 47.76 & 50 & $28.57-67.86$ & 10.71 & 82.14 & $\begin{array}{c}0.973 \\
p<0.001 \\
\mathrm{Cl}] 0.944 ; 1[\end{array}$ & \\
\hline & $\begin{array}{l}\text { Disease } \\
\text { group } 2^{\text {nd }}\end{array}$ & 53.02 & 50.00 & $40.18-71.43$ & 14.29 & 82.14 & & $0.856^{*}$ \\
\hline & $\begin{array}{l}\text { Without- } \\
\text { disease } \\
\text { group }\end{array}$ & 0 & 0 & $0.00-7.14$ & 0 & 25 & & $p<0.001^{+}$ \\
\hline \multirow[t]{3}{*}{$\begin{array}{l}\text { Score of } \\
\text { 'Functioning' } \\
\text { (No of items: 12) }\end{array}$} & $\begin{array}{l}\text { Disease } \\
\text { group } 1^{\text {st }}\end{array}$ & 26.07 & 16.67 & $4.17-50.00$ & 0 & 97.92 & $\begin{array}{c}0.929 \\
p<0.001 \\
\mathrm{Cl}[0.859 ; 0.999[\end{array}$ & \\
\hline & $\begin{array}{l}\text { Disease } \\
\text { group } 2^{\text {nd }}\end{array}$ & 28.37 & 14.58 & $7.81-50.52$ & 0 & 97.92 & & $0.496^{*}$ \\
\hline & $\begin{array}{l}\text { Without- } \\
\text { disease } \\
\text { group }\end{array}$ & 0 & 0 & $0.00-0.00$ & 0 & 0 & & $p<0.001^{+}$ \\
\hline
\end{tabular}

* Wilcoxon test between $1{ }^{\text {st }}$ and $2^{\text {nd }}$ participations; ${ }^{+}$Mann-Whitney test between patients and non-patients; Items with a scale of 1 (never - better QoL) to 5 (always - worse QoL): ROC - Receiver Operating Characteristic

diseases: ichthyosis, pruritus, alopecia, rosacea and Grover's disease. The category of non-dermatological diseases included patients attending routine consultations and many different symptoms were reported, for instance: cough, congestion, stomach pains, intolerances, other allergies, sinusitis, anaphylactic shock, allergic symptoms and routine consultations.

\section{Validity assessment}

The accuracy of the item results of Skindex-29 presented statistically significant differences when comparing distributions of disease group and without-disease group ( $p$ $<0.001$ ) and showed an expected similarity between both criteria, regarding Skindex-29 and having skin diseases (data not shown). The means of scores by dimension are presented in Table 3, as well as ROC curve values, from which it is possible to observe a good association.
Moreover, the Skindex-29 dimensions presented excellent discrimination power between groups, as described in Table 3, where the dimension 'Functioning' is the one that presents lower accuracy (ROC area $=0,929$ ) among all the evaluated dimensions, but still with an optimal accuracy value.

Table 4 reports the correlations between each item value and the score of its respective dimension, as well as the correlation between the score of each dimension and the total score of the questionnaire. It is possible to observe that every item is statistically correlated with its dimension, presenting moderate to strong correlation coefficients, with the exception of item 9 which presents weak correlation with its dimension $(r=0.279 ; p=0.052)$.

The internal consistency of each dimension of Skindex-29 was shown with high values (Table 5). Cronbach's a coefficients were above 0.80 for all 
dimensions regarding patient participation ( 0.957 for total score, 0.874 for 'Emotions', 0.835 for 'Symptoms' and 0.948 for 'Functioning').

Regarding test-retest, the concordance between both measurements was very strong, as intra-class correlation coefficients were all above 0,900:0.990 for the total score, 0.961 for 'Emotions', 0.974 for 'Symptoms', and 0.995 for 'Functioning' (Table 5). Also, the Kappa coefficient of agreement (Table 6) presented values ranging between 0.494 and 1.000 (perfect agreement: item 20), which indicates moderate, substantial, and almost perfect agreement between the questionnaires, according to Landis and Koch (1997)

Finally, and considering the disease group specifically, convergent validity of Skindex-29 with SF-12 was assessed by examining Spearman correlations between the Skindex-29 scores and the final SF-12 scores. We verified that the physical state of SF-12 was correlated only with total score (-0.478), 'Symptoms' (-0.459), and 'Functioning' $(-0.405)$ dimensions with $p<0.05$. The remaining comparisons were not statistically correlated $(p>0.005)$.

\section{DISCUSSION}

Skindex-29 appears to have evidence of validity including accuracy and reliability to be used as an instrument to evaluate the impact of skin diseases on quality of life in Portugal. Although participants commented on the fact that there are some items that seem to be repeated, it took an average of three minutes to complete the questionnaire.

The translation and back-translation steps followed the literature, ${ }^{6,21}$ and the whole design of the validation was followed by several guidelines or Skindex-29 validation examples. $2,4,5,9-11,22$

The results between patients and non-patients, as expected, were statistically different. For the internal consistency, the results were excellent for both the $1^{\text {st }}$ and $2^{\text {nd }}$ questions. As such, excellent test-retest was also shown. Finally, comparing the different dimensions with another questionnaire, the results were not as strong as expected, which may be due to the small sample size or to the large discrepancy between the results. It is recalled above that the means between patients and non-patients
Table 4 - Spearman correlation between each item results with respective dimension, and between each dimension with total score

\begin{tabular}{|c|c|c|c|}
\hline \multicolumn{2}{|c|}{ Variables for correlation } & \multirow{2}{*}{$\begin{array}{c}\begin{array}{c}\text { Spearman } \\
\text { coefficient }\end{array} \\
0.581\end{array}$} & \multirow{2}{*}{$\begin{array}{c}\boldsymbol{p} \text { value } \\
p<0.001\end{array}$} \\
\hline Q. 3 & Emotions & & \\
\hline Q. 6 & Emotions & 0.794 & $p<0.001$ \\
\hline Q. 9 & Emotions & 0.279 & $p=0.052$ \\
\hline Q. 12 & Emotions & 0.641 & $p<0.001$ \\
\hline Q. 13 & Emotions & 0.604 & $p<0.001$ \\
\hline Q. 15 & Emotions & 0.870 & $p<0.001$ \\
\hline Q. 21 & Emotions & 0.783 & $p<0.001$ \\
\hline Q. 23 & Emotions & 0.851 & $p<0.001$ \\
\hline Q. 26 & Emotions & 0.445 & $p=0.004$ \\
\hline Q. 28 & Emotions & 0.853 & $p<0.001$ \\
\hline Q.1 & Symptoms & 0.531 & $p=0.001$ \\
\hline Q.7 & Symptoms & 0.845 & $p<0.001$ \\
\hline Q. 10 & Symptoms & 0.821 & $p<0.001$ \\
\hline Q. 16 & Symptoms & 0.701 & $p<0.001$ \\
\hline Q. 19 & Symptoms & 0.890 & $p<0.001$ \\
\hline Q. 24 & Symptoms & 0.722 & $p<0.001$ \\
\hline Q. 27 & Symptoms & 0.246 & $p<0.001$ \\
\hline Q. 2 & Functioning & 0.821 & $p<0.001$ \\
\hline Q. 4 & Functioning & 0.790 & $p<0.001$ \\
\hline Q. 5 & Functioning & 0.925 & $p<0.001$ \\
\hline Q. 8 & Functioning & 0.767 & $p<0.001$ \\
\hline Q. 11 & Functioning & 0.831 & $p<0.001$ \\
\hline Q. 14 & Functioning & 0.588 & $p<0.001$ \\
\hline Q. 17 & Functioning & 0.684 & $p<0.001$ \\
\hline Q. 20 & Functioning & 0.881 & $p<0.001$ \\
\hline Q. 22 & Functioning & 0.702 & $p<0.001$ \\
\hline Q. 25 & Functioning & 0.802 & $p<0.001$ \\
\hline Q. 29 & Functioning & 0.657 & $p<0.001$ \\
\hline Q. 30 & Functioning & 0.634 & $p<0.001$ \\
\hline Emotions & Total & 0.919 & $p<0.001$ \\
\hline Symptoms & Total & 0.873 & $p<0.001$ \\
\hline Functioning & Total & 0.942 & $p<0.001$ \\
\hline
\end{tabular}

Table 5 - Reliability data: internal consistency analyzed by Cronbach' $\alpha$ and test-retest by ICC

\begin{tabular}{|c|c|c|c|c|c|}
\hline & \multicolumn{4}{|c|}{ Cronbach' $\alpha$ coefficient } & \multirow{2}{*}{$\begin{array}{c}\text { ICC } \\
\text { Between } 1^{\text {st }} \text { and } 2^{\text {nd }} \\
\text { participations }\end{array}$} \\
\hline & $\begin{array}{c}\text { Total of } \\
\text { population } \\
(n=75)\end{array}$ & $\begin{array}{l}1^{\text {st }} \text { participation } \\
\quad(n=35)\end{array}$ & $\begin{array}{l}2^{\text {nd }} \text { participation } \\
\qquad(n=26)\end{array}$ & $\begin{array}{l}\text { Without- } \\
\text { disease group } \\
(n=40)\end{array}$ & \\
\hline $\begin{array}{l}\text { Total score } \\
\text { (No of items: 29) }\end{array}$ & 0.975 & 0.957 & 0.957 & 0.797 & 0.990 \\
\hline $\begin{array}{l}\text { Score of 'Emotions' } \\
\text { (No of items: 10) }\end{array}$ & 0.928 & 0.874 & 0.840 & 0.476 & 0.961 \\
\hline $\begin{array}{l}\text { Score of 'Symptoms' } \\
\text { (No of items: } 7 \text { ) }\end{array}$ & 0.919 & 0.835 & 0.802 & 0.722 & 0.974 \\
\hline $\begin{array}{l}\text { Score of 'Functioning' } \\
\text { (No of items: 12) }\end{array}$ & 0.962 & 0.948 & 0.956 & 0.563 & 0.995 \\
\hline
\end{tabular}


Table 6 - Test-retest, Kappa coefficient for $1^{\text {st }}$ and $2^{\text {nd }}$ participations

\begin{tabular}{llll}
\hline \multicolumn{3}{l}{ Kappa concordance coefficient for $\mathbf{1}^{\text {st }}$ and $2^{\text {nd }}$ participations } \\
\hline P1 & 0.696 & P16 & 0.948 \\
P2 & 0.751 & P17 & 0.841 \\
P3 & 0.788 & P19 & 0.702 \\
P4 & 0.848 & P20 & 1.000 \\
P5 & 0.494 & P21 & 0.680 \\
P6 & 0.645 & P22 & 0.773 \\
P7 & 0.796 & P23 & 0.803 \\
P8 & 0.876 & P24 & 0.833 \\
P9 & 0.657 & P25 & 0.823 \\
P10 & 0.741 & P26 & 0.875 \\
P11 & 0.693 & P27 & 0.876 \\
P12 & 0.779 & P28 & 0.699 \\
P13 & 0.701 & P29 & 0.849 \\
P14 & 0.846 & P30 & 0.842 \\
P15 & 0.742 & & \\
\hline
\end{tabular}

$p<0.001$

were similar, while the mean of Skindex-29 was different. This fact suggests that dermatological patients assume a general health similar to other individuals, but when they talk about their specific disease, they reveal some lower levels of QoL.

The aim of this study was not to make a comparison with the original version of Skindex-29, but it was possible to point out some similarities and differences, although with some different methods. Beginning with the internal consistency, for the original study, the Cronbach's a coefficient values were $0.87 ; 0.94 ; 0.96$ for the 'Symptoms', 'Emotions' and 'Functioning' dimensions, respectively ${ }^{23}$ and in the present study were $0.835 ; 0.874 ; 0.948$, by the same order. For test-retest, the Portuguese study used the ICC with values of $0.974,0.961$ and 0.995 for the dimensions 'Symptoms', 'Emotions' and 'Functioning', respectively. In turn, the original study presented the following Spearman's correlation coefficient values: $0.91 ; 0.88$ and 0.92 for the same order. Finally, regarding convergent validity, the comparison with another QoL questionnaire, the original case used the SF-36, and it was found that in both studies the means for patients and non-patients were similar in the general questionnaire, with statistically significant results. ${ }^{12}$ However, by comparing the SF subscales and the dimensions of Skindex-29, it was observed that in the original the correlations were statistically significant, whereas in the present study, only the SF-12 Physical Component dimension with the total score was statistically significant and Skindex-29 'Functioning' and 'Symptom' questions. This conclusion points to the possibility that the Skindex-29 questionnaire is better able to assess the QoL regarding physical components rather than mental or emotional components.

Comparing with other validations, there is some difference in methodology. For some versions, instead of comparing results between patients and non-patients, they did so between groups of dermatological diseases of different stages and severity levels, as in Spain, ${ }^{4}$ Turkey, ${ }^{10}$ Italy ${ }^{9}$ or China. ${ }^{22}$ The internal consistency evaluation was based on the same methodology and the results between the various validations were very similar. Not all countries analyzed reproducibility or did not express the values in the corresponding article, and so did the comparison between the patient and non-patient questionnaire values.

There is some difference in the methodology regarding the comparison between two different questionnaires, but for all validations, Skindex-29 is positively validated between the different languages. With other validations like the cases of Poland, ${ }^{11}$ Colombia $^{8}$ and Argentina, ${ }^{7}$ the methodology was somewhat different. Since the questionnaire is already validated by internal consistency and test-retest, these authors focused more on the factorial analysis between the Skindex-29 items after being translated into their respective languages.

One limitation in the present study is the lack of heterogeneity among dermatological diseases. With higher number of diseases and greater number of individuals with these diseases, the scores between diseases could have been studied and compared.

With a larger sample, the results could have been more relevant, although they were very similar to other validations. The methodology used in this validation seemed adequate and sufficient.

Throughout the data collection, it was found that, even with a severe dermatological disease, patients responded that their overall health was good. That is, they certainly 'forget' the disease they have when they talk about health at the general level. This fact has been repeated in different patients, which leads one to believe that in Portugal, although the levels of severity of dermatological diseases are high, there is some undervaluation of these diseases in general health. It may be because patients do not consider their own disease to be severe enough or because at the social level these diseases are not known to be serious and chronic.

Several studies have already shown that the clinical severity of the disease may not correspond to patient perception and that patients and physicians, including dermatologists, often assess patients' QoL differently. ${ }^{9}$ An accurate and reliable QoL measure has a significant potential for assisting policy and clinical decisions in dermatology, and Skindex-29 is a useful measure for clinical trials, health care research, clinical practice, and cost-utility analysis. It can also be used by clinicians in their daily practice to assess the impact of the disease on the QoL of their patients and to monitor over time. ${ }^{9}$

There are other dermatology-specific QoL instruments validated for European Portuguese, but it is important to validate Skindex-29 for several reasons. The fact that there is one more questionnaire available for this type of evaluation offers both health professionals and policy 
makers the opportunity to choose the one that best fits the intended objective. Other reasons are that, since Sikidex-29 presents some similar questions, it may equally well be able to assess the patient's responsiveness without having to resort to another complementary instrument.

\section{CONCLUSION}

This preliminary evaluation of the measurement properties of the Portuguese version of Skindex-29 suggests that it is an accurate and reliable measure of QoL in Portuguese patients with dermatological disease.

\section{ACKNOWLEDGMENTS}

The authors would like to thank Rui Bajanca (Dermatologist at Dermacare Clinic) for the help and for having his clinic available for data collection. A special thanks is dedicated to Charlotte Scott (Master of Biochemistry, University of Oxford, currently working as a research assistant at UCL Great Ormond Street Institute of Child Health), who reviewed the language of the article, as

\section{REFERENCES}

1. Stalder JF, Tennstedt D, Deleuran M, Fabbrocini G, De Lucas R, Haftek $\mathrm{M}$, et al. Fragility of epidermis and its consequence in dermatology. J Eur Acad Dermatology Venereol. 2014;28:S1-18.

2. Kini SP, DeLong LK. Overview of health status quality-of-life measures. Dermatol Clin. 2012;30:209-21.

3. World Health Organization. WHOQOL: measuring quality of life [Internet]. Geneva; 1997. [cited 2017 Apr 5]. Report No.: WHO/MSA/ $\mathrm{MNH/PSF/97.4.}$

4. Jones-Caballero M, Peñas PF, García-Díez A, Badía X, Chren MM. The spanish version of Skindex-29. Int J Dermatol. 2000;39:907-12.

5. Augustin M, Wenninger K, Amon U, Schroth MJ, Küster W, Chren M, et al. German adaptation of the skindex-29 questionnaire on quality of life in dermatology: validation and clinical results. Dermatology. 2004;209:14-20.

6. Guillemin F, Bombardier C, Beaton D. Cross-cultural adaptation of health-related quality of life measures: literature review and proposed guidelines. J Clin Epidemiol. 1993;46:1417-32.

7. Khaski S, Cortada AK, Errecaborde M, Oliveira G, Achenbach RE, Lococo LJ. Estudio piloto de validación de Skindex-29 en población argentina. Rev Argentina Dermatología. 2016;97:7.

8. Sanclemente G, Lugo LH, Medina L, Jones-caballero M, García HI. Preprueba para la adaptación cultural de la versión española del instrumento de calidad de vida dermatológico Skindex-29, en Colombia. Rev Asoc Colomb Dermatología. 2011;19:273-9.

9. Abeni D, Picardi A, Pasquini P, Melchi CF, Chren MM. Further evidence of the validity and reliability of the Skindex-29: an Italian study on 2,242 dermatological outpatients. Dermatology. 2002;204:43-9.

10. Aksu AE, Urer MS, Sabuncu I, Saracoglu ZN, Chren M-M. Turkish version of Skindex-29. Int J Dermatol. 2007;46:350-5.

11. Janowski K, Steuden S, Bereza B. The polish version of Skindex-29: psychometric properties of an instrument to measure quality of life in dermatology. Postep Dermatology Alergol. 2014;31:12-20.

12. Paula HR de, Haddad A, Weiss MA, Dini GM, Ferreira LM. Translation, cultural adaptation, and validation of the American Skindex-29 quality of life index. An Bras Dermatol. 2014;89:600-7.

13. Chren M-M, Lasek RJ, Quinn LM, Covinsky KE. Convergent and discriminant validity of a generic and a disease-specific instrument to measure quality of life in patients with skin disease. J Invest Dermatol. well as John Stewart Huffstot, a director of English-language studies and professor at Universidade Nova de Lisboa, for the proof-read.

\section{PROTECTION OF HUMAN AND ANIMAL SUBJECTS}

The authors declare that the research procedures were performed according to the regulations of the institution's ethics committee and the Code of Ethics of the World Medical Association (Declaration of Helsinki).

\section{CONFIDENTIALITY OF DATA}

The authors declare that they have followed the protocols of their work centre regarding the publication of data from patients.

\section{CONFLICT OF INTEREST}

No conflict of interest has been declared by any author.

\section{FUNDING}

No financial support was received by any author.

1997;108:103-7

14. Aguiar $P$, Neto D, Lambaz R, Chick J, Ferrinho P. Prognostic factors during outpatient treatment for alcohol dependence: Cohort study with 6 months of treatment follow-up. Alcohol Alcohol. 2012;47:702-10.

15. Stalder JF, Taïeb A. Clinical validation and guidelines for the SCORAD index: consensus report of the European task force on atopic dermatitis. Dermatology. 1997;195:10-9.

16. Charman CR, Venn AJ, Williams HC. Reliability testing of the Six Area, Six Sign Atopic Dermatitis severity score. Br J Dermatol. 2002;146:105760.

17. QualityMetric. SF-12v2 Health Survey [accessed 2017 Apr 5]. Available from: http://campaign.optum.com/optum-outcomes/what-we-do/healthsurveys/sf-12v2-health-survey.html.

18. Aguiar $P$, Silva $C$, Negreiro F, Vicente V. Quais os aspectos essenciais na validação de um questionário? Vol. n¹9A, Cartas do amigo GAUSS Eurotrials Scientific Consultants; 2012. p. 2.

19. Marôco J. Análise estatística com SPSS statistics. $5^{\text {a. }}$. Pero Pinheiro: ReportNumber; 2011. p. 990.

20. Cerda J, Villarroel L. Evaluación de la concordancia inter-observador en investigación pediátrica: coeficiente de Kappa. Rev Chil Pediatría. 2008;79:54-8.

21. Landis JR, Koch GG. The measurement of observer agreement for categorical data. Biometrics. 1977;33:159-74.

22. Chren MM. Interpretation of quality-of-life scores. J Invest Dermatol. 2010;130:1207-9.

23. He Z, Lu C, Chren MM, Zhang Z, Li Y, Ni X, et al. Development and psychometric validation of the Chinese version of Skindex-29 and Skindex-16. Health Qual Life Outcomes. 2014;12:1-11.

24. Iarossi G. O poder da concepção em inquéritos por questionário. $1^{\mathrm{a}}$ ed. Lisboa: Fundação Calouste Gulbenkian; 2011. p. 359.

25. Chren MM, Lasek RJ, Flocke SA, Zyzanski SJ. Improved discriminative and evaluative capability of a refined version of skindex, a qualityof-life instrument ofr patients with skin diseases. Arch Dermatol. 1997;133:1433-40.

26. Sampogna F, Abeni D. Interpretation of Skindex-29 scores. J Invest Dermatol. 2011;131:1790-3.

27. Chren MM. The Skindex instruments to measure the effects of skin disease on quality of life. Dermatol Clin. 2012;30:231-6. 